the army posts, as the direct result of drink bonght over the canteen bur from the special official military bartenders. Can Dr. Keen prove that "beer" never had why part in these afraira? He pleads for beer-or the so-called Bartholdt bill does. And he defends it from lis stundpoint as a physician, especially because he muintains that without the canteen immorality in the ranks of the army is on the increase, with all its truly deploruble results. But as to lis nrgument that the canten keeps the soldiers from the worse snloons and brothels outside, we are told that those places always flourished very near to the army posts during all the cninteen years, and that the results of ubolishing the canteen lave been gool, insteal of bad. The burden of proof to the contrary rests on those who petition Congress to puss the Bartholdt bill. The fact-if it is a fact-that certain disenses are on the incrense in the nrmy, is not proved to be simply and solely due to the nbolishing of the eurteen.

It is a well-known and established fact that selectel normal, netive men, especinlly lusbands, to not seek or consort with prostitutes, unless their animal passions are first nroused by stimulating drugs and intoxiennts. Therefore, as a remedy for the horrible conditions which Dr. Keen describes, and quotes authority to prove:

1. Let the United States Army clenn camp, insisle as woll ns outsile. If illicit suloons, dives and spenk-casies exist and thrive around Uncle Sam's police stations to thut extent, in the nume of God and for the honor of the army of humanity and expansion, let these evil pliees be put to rout. If they are illegal places of mornl degradation such ns pictured, it certainly is within the power, and would be much easier for the War Department to cleun them up, than it would if they became legal pluces of moral degradation.

2. Let the War Depurtment establish all military posts in places where the liquor traffic has been ontlawed; there are plenty of them scattered at strategic points throughout the United States. Then it will be ensy for General Wood to keep his camps clean.

3. Let the President spend nbout flfteen minutes under his well-defined authority, in transmitting an executive order to the Department of the Interior, directing the Commissioner of Interual Revenue to stop issuing permits to brewers and dis. tillers to sell intoxieating liquors in states which have ontlawed such sale, so that the general government no loiger shall comnive at the brenking of the solemnly enneted luws of a coordinate branch. And let the War Department conpernte with the Interior Department to put an end to this species of anarehy. Or, in other words, while the patient yet retains good vitality, let the skilled humane surgeon cut out the last tissue of cancerous growth.

It is my personal conviction that the liquor business is $\mathrm{n}$ evil. thing and that it is wrong in principle for the govermment to engige in any undertaking that incvitably wenkens and debases the men who are sworn to support and defend it, and it is for this reason that I reply to Dr. lieen.

$$
\text { Join G. Wilson, Montrose, Pa. }
$$

\section{Cook Versus Peary}

To the Lditor:-Dr. Cook lectured at New Kensington, Pn., Jan. 3, 1912, advertising previously in one of the local papers that "Dr, Cook himself will arswer the claims of Penry and the members of the Peary party".

It is with the grentest reluctance that $I \mathrm{~nm}$ compelled to Answer and perhaps question the veracity of an explorer who is a member of my profession. Dr. Cook, however, lenves mo no choice in the matter, since he lectured in the Columbis Theater, across the street from my oflice, and gives to the press a distorted version of Rudolph Franke's reception on the Roosevelt nt lituh. The matter is extremely distasteful, but in justice to Admiral Peary, myself and the oflicers of tho Rooscvelt I am compellel to deny Dr. Cook's insinuntions that his companion, Rudolph Franke, nfficted with seurvy and, applying on the Roosevelt at Etuh for medicnl nttention and food, was refused, until Commander leary had extorted terms discredituble to all concerned.
I have always regarded Dr. Cook with the kindliest feeling and for the honor of my profession had hoped that J)r. Cook might liave vindicated his verneity. I. trust that he will correct the version of Franke's reception on the Rooscvelt written in his book, spoken from the platform and illustrated throughont the country by moving pictures.

Jomn W. Goonseld, New liensington, Pn. Surgeon Peury Aretic Jipedition, 1908-1909.

\section{Mounting Pathologic Specimens}

To the . Editor:--I wish to give a few suggestions to those mounting gross pathologic specimens. In putting up a great many specimens in gelutin, I always had the trouble of airbubbles forming. as well as discoloration of the gelntin and sometimes of the specimens themselves. Not only lias the method these faults but it is also expensive. If one wants to freshen up gelatin-mounted spccimens, it is necessnry to break the seal and take off the gelatin and remount them.

The method I now use is very eheap; in fact, ench specimen costs abont 10 cents and no speeinl jurs or dishes are required. The specimens are first prepared by Kiaiserling's method, which is its follows:

\section{Fixation for one to five days in :}

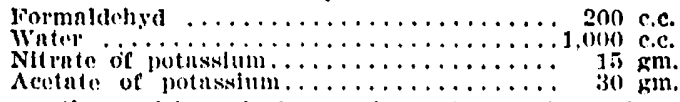

Change the position of the specimen frequently the flue of fixition varfes with the tlssuc or orgin nud slzc of the specimen.

2. Jurnin and place in $80 \mathrm{per}$ cent. nicohol for one to six lours, nnil then in 95 per cent. nleuliol for one to two hours, to restore the color, which is somewhat afrected in the fing solution.

3. I'rescive in :

Acetute of potasslum............ $200 \mathrm{gm}$

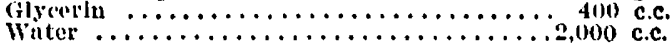

Since exposiure to light roduces the color contrasts, the specimel should be prepured and kept in the dark.- (1)elufleld aud pludden: IIandbook of L'illyologic Anatomy, phige (61.)

The specimens are then mounted on celluloid. I use the kind of celluloid of which automobile curtnins are made. The specimens of intestines and nppendices and soft.tissue may be sewed on to the celluloid and mounted in ordinary glass pre. serving jars. 'Tlie jars are then filled with No. 3 líniserling.

Another alvuntage of this method is that it gives one an opportunity to cut out that part of the celluloid which might distort the specimens, which cannot be clone if glass is used. Under the specimens white lead may be used to put on the diagnosis. The jar is filled with No. 3 Kniserling, which has been filtered and is perfectly clear. By submerging the jar in a larger vessel of the kniserling solution it may be filled without any air-bubbles. This makes a very pretty mount. ing as the celluloid is invisible and the solution is as clear as crystal.

The specimens may be taken out at ally timo and refreshened in nlcohol; there are no labels on the bottle to be washed ofl; hent or cold will not affect them and they may be mounted very quickly.

Inary M. Weoeforth, M.D., San Diego, Cal.

\section{Condensed Milk in Nevada}

To the Elitor:-In the discussion of Dr. Nell's article on "Rerent Experiences in the Artificial Feeding of One IHundred Infants" ("line Journat, Dee, 23, 1911, p. 2068), Dr. R. 13. Tubbs, of Council Blulfs, In., says that he "camnot sec why it is any more legitimate for us to give condensed milk thin it is to give proprietary medicines." I wish to ask Dr. Tubbs what he would advise using in place of condensed milk out here in the Nevada deserts, 65 miles from railrond and 60 miles from tihe nearest milk cow or gont. I have no startling results to record from its use, but the babies under my care are holding their own through careful attention to dilutions, time of feceling, etc.

E. N. Ronerts, Wonder, Nev. 